\title{
Increased quality of small-scale organic compost with the addition of efficient microorganisms
}

Melhoria da qualidade de composto orgânico em pequena escala com adição de microrganismos eficientes

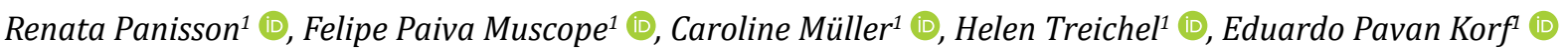

\section{A B S T R A C T}

Substantial quantities of solid livestock waste are potential sources of nutrients for agroecological production on small-scale farms. However, processes used to manage and dispose of this type of waste must be able to eliminate pathogenic microorganisms. This work aimed to evaluate composting and vermicomposting processes by inoculating efficient microorganisms (EMs) at the field level. Composting and vermicomposting were performed with a mixture of cattle and goat manure and sawdust (2:1:1), with the inoculation of EMs at concentrations of 0,2 , and $4 \mathrm{~mL} \mathrm{~L}^{-1}$. In vermicomposting experiments, Lumbricus rubellus (100 g $250 \mathrm{dm}^{-3}$ substrate) were inoculated. After the maturation and stabilization phases of the compost, concentrations of organic carbon, macronutrients, micronutrients, heavy metals, thermotolerant coliforms, and Salmonella spp. were analyzed. The composting experiments, regardless of the presence of EMs, have been shown to have higher humidity. Also, the final compost had a lower $\mathrm{pH}$ value. Macronutrients, such as $\mathrm{P}, \mathrm{K}, \mathrm{Ca}$, and $\mathrm{S}$, were observed to a greater extent in the composting experiments associated with $4 \mathrm{~mL}$ of EMs (EM4); while organic carbon and Mg were higher in vermicomposting. The vermicomposting process also allowed for more effective elimination of pathogens, such as thermotolerant coliforms, especially when associated with $2 \mathrm{~mL}$ of EMs (EM2). The compost products produced allowed waste with potential agroecological use to be recognized as important.

Keywords: vermicomposting; waste recovery; pathogens; organic fertilizer.

\section{R E S U M 0}

Quantidades substanciais de resíduos sólidos provenientes da bovinocultura são fontes potenciais de nutrientes para a produção agroecológica em agricultura de pequena escala. Os processos de tratamento e disposição desses resíduos, entretanto, devem ser capazes de eliminar os microrganismos patogênicos. Nesse sentido, este trabalho objetivou avaliar os processos de compostagem evermicompostagem por meio da inoculação de microrganismos eficientes (EMs) em escala de campo. A compostagem e a vermicompostagem foram realizadas com esterco bovino, caprino e serragem (2:1:1), com a inoculação de EMs nas concentrações de 0, 2 e $4 \mathrm{~mL} \mathrm{~L}^{-1}$. Em experimentos de vermicompostagem, Lumbricus rubellus foram inoculadas (100 g $250 \mathrm{dm}^{-3}$ substrato). Após as fases de maturação e estabilização dos compostos, analisaram-se as concentrações de carbono orgânico, macronutrientes, micronutrientes, metais pesados, coliformes termotolerantes e Salmonella spp. Com os resultados obtidos, foi possível verificar que os experimentos de compostagem, independentemente da presença de EMs, apresentaram maior umidade e menor $\mathrm{pH}$ no composto final. Os macronutrientes como $\mathrm{P}, \mathrm{K}, \mathrm{Ca}$ e $\mathrm{S}$ foram observados em maior teor nos experimentos de compostagem associados a EM4, enquanto carbono orgânico e $\mathrm{Mg}$ foram maiores na vermicompostagem. O processo de vermicompostagem, ainda, permitiu remoção mais eficaz de patógenos como os coliformes termotolerantes, principalmente quando associado a EM2. Os compostos produzidos propiciaram a valorização dos resíduos com potencial uso para a produção agroecológica.

Palavras-chave: vermicompostagem; reciclagem e aproveitamento de resíduos; patógenos; fertilizante orgânico.

\footnotetext{
${ }^{1}$ Universidade Federal da Fronteira Sul - Erechim (RS), Brazil.

Correspondence address: Eduardo Pavan Korf - Universidade Federal da Fronteira Sul - ES 135, km 72, 200 -CEP: $99700-970$ - Erechim (RS), Brazil. E-mail: eduardo.korf@uffs.edu.br

Conflicts of interest: the authors declare that there are no conflicts of interest.

Funding: Chamada Universal MCTI/CNPq (Editais Universal/403454/2016-6 \& Produtividade em Pesquisa/310805/2020-1).

Received on: 10/11/2020. Accepted on: 06/24/2021

https://doi.org/10.5327/Z21769478949
} 


\section{Introduction}

In order to meet growing demands for food, over-cropping and overuse of inorganic fertilizers have become common practices among farmers. However, replacing organic with inorganic inputs reduces soil quality and can lead to environmental pollution (Albiach et al., 2000; Komiyama et al., 2013). This can be avoided with the use of organic solid waste fertilizers, through composting or vermicomposting. These processes improve microbial activity (Ros et al., 2006; Knapp et al., 2010; Elbl et al., 2019), and increases soil cation exchange capacity, which favors mineralization and nutrient recycling (Nath and Singh, 2012; Domínguez and Gómez-Brandón, 2013; Yadav and Garg, 2016). On the other hand, the direct use of solid animal waste (e.g. manure) as fertilizer is not recommended because this type of waste can contain high pathogen loads (Larney and Hao, 2007; Lim et al., 2016), which can cause soil and water contamination (Ciancio et al., 2014; Ciapparelli et al., 2016). Thus, composting or vermicomposting processes must provide stable, pathogen-free, and soil-beneficial end-products. The main challenge of these processes is to control and optimize the interactions between the biological, chemical, and physical mechanisms affecting the composition and degradation behavior of heterogeneous organic matrices, such as organic waste (Hemidat et al., 2018).

The composting process involves various temperature ranges. In the thermophilic phase of humification, at ideal temperatures between 50 and $70^{\circ} \mathrm{C}$, pathogenic microorganisms are eliminated (Misra et al., 2003). In the context of small-scale composting or vermicomposting, problems usually occur because the temperature is not raised and maintained at desirable values (above $50^{\circ} \mathrm{C}$ ) in the thermophilic phase; resulting in incomplete elimination of pathogens. This results in incorrect composting and generates final products with lower quality than that required by the national and international legislation. Some studies have reported home-scale experiments with temperatures below $45^{\circ} \mathrm{C}$, demonstrating the limitation of composting at this level (Ermolaev et al., 2014; Faverial and Sierra, 2014).

As an alternative, efficient microorganisms (EMs) have been used to improve microbial activity. EMs represent a consortium of beneficial microorganisms, including photosynthetic bacteria, yeast, actinomycetes, and fermenting fungi, among others (Sigstad et al., 2013; Diering, 2020). Diering (2020) observed that the majority of these microorganisms included Zygotorulaspora florentina (53.7\%) and Pichia nakasei (46.0\%) fungi, and Gluconobacter cerinus (78.5\%), Lactobacillus casei (8.0\%), and Gluconobacter frateurii (6.8\%) bacteria. Increasing microbial load using EMs improves the chemical and physical properties of the compost, significantly affecting temperature and decomposition rates during composting, all of which contribute to a sustainable and high-quality final product (Jusoh et al., 2013; Patidar et al., 2013; Zhong et al., 2018). During organic matter composting with EMs, it was possible to verify an increase in the levels of $\mathrm{C}$ and $\mathrm{N}$ in the compost derived from fruit residues (Raja Namasivayam and Bharani, 2012) and a mixture of rice straw, goat manure, and green residues (Jusoh et al., 2013), as well as an increase in macronutrients in the compost produced from corn by-products (Hendriani et al., 2017). EMs, even when used with a reduced dose of chemical fertilizers, have been described to increase the content of humus and organic carbon in the soil, and to improve its fertility, when compared to the application of chemical fertilizers alone (Sharma et al., 2017). High efficiency in nutrient availability has also been observed in vermicomposting processes using EMs (Hénault-Ethier et al., 2016). In addition, the optimized combination of EMs allows for reduced odors released by the decomposition of organic matter, thus contributing to reduced pathogens in the compost (Calderón-Tapia et al., 2020). Nevertheless, studies are scarce, especially those focused on the removal of pathogens (thermotolerant coliforms and Salmonella) from agricultural waste composting in small rural properties.

Therefore, we used composting and vermicomposting methods in the present study, using organic residues with various concentrations of EMs at the field level, on small rural properties, to eliminate pathogens and generate a high-quality final compost product.

\section{Material and Methods}

\section{Experimental design and treatments}

The experiments were conducted using windrow composting, including composting or vermicomposting (with Lumbricus rubellus), and efficient microorganisms (EMs) were added at three concentrations: $0 \mathrm{~mL} \mathrm{~L}^{-1}, 2 \mathrm{~mL} \mathrm{~L}^{-1}$, and $4 \mathrm{~mL} \mathrm{~L}^{-1}$. Treatment groups were as follows:

- COMP (composting);

- COMP+EM2 (composting and $2 \mathrm{~mL} \mathrm{~L}^{-1} \mathrm{EM}$ );

- COMP+EM4 (composting and $4 \mathrm{~mL} \mathrm{~L}^{-1} \mathrm{EM}$ );

- VERM (vermicomposting);

- VERM+EM2 (vermicomposting and $2 \mathrm{~mL} \mathrm{~L}^{-1} \mathrm{EM}$ );

- VERM+EM4 (vermicomposting and $4 \mathrm{~mL} \mathrm{~L}^{-1} \mathrm{EM}$ ).

The data obtained were analyzed by descriptive statistical analysis, with mean and standard deviation for data collected in triplicates.

\section{Obtaining the microorganisms}

Native efficient microorganisms were captured inside the forest area in a horticulture production farm in Erechim, Rio Grande do Sul, Brazil (-27.53301 S, $-52.32665 \mathrm{~W}$ ) and multiplied according to Bonfin et al. (2011). Boiled rice, wrapped in a shading screen, was covered with litter and maintained for 15 days in an area of virgin forest $(7 \mathrm{~m}$ from the border), under average temperature from 15 to $20^{\circ} \mathrm{C}$. After this period, the microorganisms found in the collected material were selected by staining for multiplication. Gray, white, brown, and black rice grains were discarded. The other-colored grains were multiplied by fermentation process in a culture medium containing an aqueous solution of sugarcane molasses (20\%), for two months, for the development and bioaugmentation of efficient microorganisms. The mixture was kept in an expandable and air-tight container, and the gases were released when necessary. 


\section{Substrate preparation}

The substrates used in all treatments were prepared with the combination of cattle manure, goat manure, and sawdust as the structuring medium. After analyzing the baseline characterization of carbon $(\mathrm{C})$ and nitrogen $(\mathrm{N})$ for each residue, the mass balance was calculated for various combinations, as indicated in Equation 1:

$\frac{C}{N}$ ratio $=\frac{\left(\% C M \times C_{C M}\right)+\left(\% G M \times C_{G M}\right)+\left(\% S \times C_{S}\right)}{\left(\% C M \times N_{C M}\right)+\left(\% G M \times N_{G M}\right)+\left(\% S \times N_{S}\right)}$

Where:

$\mathrm{CM}=$ cattle manure (\%);

$\mathrm{GM}=$ goat manure (\%);

$\mathrm{S}=$ sawdust $(\%)$;

$\mathrm{C}=$ carbon $(\%)$;

$\mathrm{N}=$ nitrogen $(\%)$.

To achieve $\mathrm{C} / \mathrm{N}$ ratios ranging from 20:1 to 35:1 (Herberts et al., 2005 ), the defined ratio was $50 \%$ cattle manure, $25 \%$ goat manure, and $25 \%$ sawdust.

The substrates used in the composting experiments were prepared using a 400-L concrete mixer with a 2-HP single-phase motor. After determining the baseline moisture content using reflectometry (TDR, model 6005L, MiniTRASE, Armidale, NSW, AU), the compost was added to windrow layers consisting of $30 \mathrm{~kg}$ of compost and $10 \mathrm{~L}$ of water. In experiments using EMs, these were diluted and inoculated with water. In the composting experiments, the soil was stirred up with a drill 3 times a week, until the maturation phase was reached. After this period, the soil was stirred up twice a week and, in the final fifteen days of the experiments, it was stirred up once a week.

For the vermicomposting experiments, $100 \mathrm{~g}$ of Lumbricus rubellus, commonly known as red wriggler, were added to $250 \mathrm{~kg}$ of substrate $\left(0.4 \mathrm{~g}\right.$ earthworms $/ \mathrm{dm}^{3}$ substrate) during compost preparation in the absence of turning.

The composting and vermicomposting experiments were conducted for 120 and 150 days, respectively. In both experiments, an aqueous solution containing EMs was replenished five times over the 150 experimental days, in the same proportion of water replenished in the experiments without EMs, considering the need for tactile analysis. Regardless of the addition of EMs, all experiments received the same total volume of water.

The experiments were carried out in windrows, made up of $1 \times 1 \times$ $0.7 \mathrm{~m}(\mathrm{l} \times \mathrm{w} \mathrm{xh})$ wooden boxes, with a volume of $0.7 \mathrm{~m}^{3}$, and a capacity for $250 \mathrm{~kg}$ of initial substrate, as suggested for small-scale uses by Faverial and Sierra (2014). The windrows were shaded and covered to prevent external effects caused by rainfall and slurry generation.

\section{Evaluations}

Substrate temperature was monitored daily using a portable thermometer with a $-50^{\circ} \mathrm{C}$ to $200^{\circ} \mathrm{C}$ measuring range and accuracy of $\pm 0.5^{\circ} \mathrm{C}$ (model AK904, AKSO, São Leopoldo, Brazil). Humidity and $\mathrm{pH}$ were assessed at the beginning (BASELINE), before treatment (EMs and earthworms), and at the end of the experiments (after 150 or 120 days). Humidity was measured by gravimetric method, which consists of weighing the sample before and after being dried in an oven $\left(65^{\circ} \mathrm{C}\right)$, to calculate humidity based on the dry mass. $\mathrm{pH}$ was determined using a laboratory pH meter (model 8650, AZ Instrument, Taichung, Taiwan).

Visual tactile analysis was done in loco according to Nunes (2009) to verify compost stability and humidity during testing and to determine how often water and/or EM aqueous solution should be added. The visual tactical analysis consists of manually obtaining a sample of the material from inside the windrow and pressing it firmly to verify water leakage without draining it.

At the beginning and end of the process, $\mathrm{pH}$, thermotolerant coliforms, Salmonella spp., organic carbon, and macro and micronutrients, as well as heavy metal concentrations, were analyzed.

\section{Thermotolerant coliforms}

The number of thermotolerant coliforms was determined according to the 9221E methodology (Braun-Howland et al., 2017). Samples were initially incubated in tryptose lauryl sulfate broth (LST) at $37^{\circ} \mathrm{C}$ for $24 \mathrm{~h}$. After confirmation of gas production, an aliquot of each culture was transferred to new tubes with a medium containing lactose, ox gall, and brilliant green at $44.5^{\circ} \mathrm{C}$ for $24 \mathrm{~h}$ The most probable number (MPN) method was used for quantification. Only dishes at the same dilution with 30 to 300 colonies were considered for counting. The arithmetic mean of the colonies was multiplied by the respective dilution factor and the results were expressed as NMP g-1.

\section{Determination of Salmonella ssp.}

The amount of Salmonella spp. was determined qualitatively by the presence/absence technique using VIDAS $^{\circledR}$ Easy Salmonella Method (Adria Développement, Quimper Cedex, France), according to the manufacturer's recommendations. The samples were initially enriched with buffered peptone water (BPW) and maintained at $37^{\circ} \mathrm{C}$ for approximately $20 \mathrm{~h}$. The subculture was then transferred to SX2 broth (Salmonella Xpress 2) $(0.1 \mathrm{~mL}+10 \mathrm{~mL})$ and incubated for approximately $24 \mathrm{~h}$ at $41.5^{\circ} \mathrm{C}$. Samples were then transferred to a microtube, heated to $100^{\circ} \mathrm{C}$ for $15 \mathrm{~min}$ and, after cooling, $0.5 \mathrm{~mL}$ was transferred to VIDAS SLM strips. Fluorescence was measured at $450 \mathrm{~nm}$. The values were compared to internal references and each result was interpreted as positive or negative.

\section{Organic carbon and mineral elements}

Organic carbon (C), macronutrients ( $\mathrm{N}, \mathrm{P}, \mathrm{K}, \mathrm{Ca}, \mathrm{Mg}, \mathrm{S})$, and micronutrients ( $\mathrm{Mn}, \mathrm{Cu}, \mathrm{Zn}, \mathrm{Fe}, \mathrm{B}$ ) were determined according to Brasil (2017), and heavy metals (Cd, Pb, Cr, Ni) according to USEPA (1998). All analyses were performed in triplicate. 


\section{Results}

The temperature outside the windrows was similar between the composting and vermicomposting experiments, with average temperatures of $26.0 \pm 3.1^{\circ} \mathrm{C}$ and $26.8 \pm 3.7^{\circ} \mathrm{C}$, respectively (Figure 1). The maximum temperatures found inside the windrows were $49^{\circ} \mathrm{C}$, $50^{\circ} \mathrm{C}$, and $51^{\circ} \mathrm{C}$ in the experiments that did not use EMs, that used $2 \mathrm{~mL} \mathrm{~L}^{-1}$, or that used $4 \mathrm{~mL}^{-1} \mathrm{EMs}$, respectively. In the vermicomposting experiments, the maximum temperatures found were $48^{\circ} \mathrm{C}$ (VERM), $48^{\circ} \mathrm{C}$ (VERM+EM2), and $47^{\circ} \mathrm{C}$ (VERM+EM4).

The experiments containing $2 \mathrm{~mL} \mathrm{~L}^{-1}$ EMs recorded temperatures above $40^{\circ} \mathrm{C}$ for a longer time, and the shortest time at these temperatures was recorded in the vermicomposting experiments with the highest concentration of EMs $\left(4 \mathrm{~mL} \mathrm{~L}^{-1}\right)$ (Figure 1$)$.

The initial substrate used in all experiments had $71.6 \%$ humidity and $\mathrm{pH} 8.1$ (Table 1). After the experimental period, the substrates used for composting and vermicomposting had average $\mathrm{pH}$ values of 7.4 and 6.8, respectively, regardless of the addition of EMs. Humidity ranged from 50 to $67 \%$ over the experimental period.

The content of macronutrients in the substrates used for composting and vermicomposting changed at the end of the experiments compared to baseline levels. Reductions in $\mathrm{C} / \mathrm{N}$ ratios and $\mathrm{C}$ content were observed for both composting and vermicomposting compared to the content found in the initial substrate. Amounts of $\mathrm{N}, \mathrm{P}, \mathrm{Ca}, \mathrm{Mg}$, and S increased in all experiments. $\mathrm{K}$ was found at higher values in the composting experiments only, regardless of the presence of EMs (Table 2).

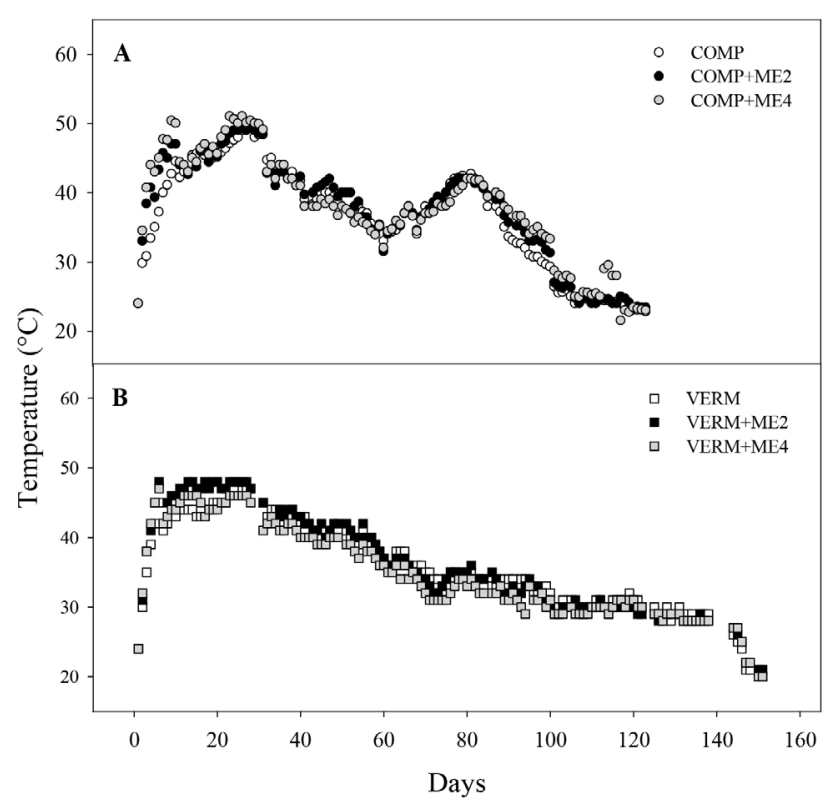

Figure 1 - (A) Windrow temperature of composting (COMP), composting with $2 \mathrm{~mL} \mathrm{~L}^{-1}$ of efficient microorganisms (COMP+2EM), and composting with $4 \mathrm{~mL} \mathrm{~L}^{-1}$ EMs (COMP+4EM); (B) vermicomposting (VERM), vermicomposting with $2 \mathrm{~mL} \mathrm{~L}^{-1}$ EMs (VERM+2EM), and vermicomposting with $4 \mathrm{~mL} \mathrm{~L}^{-1}$ EMs (VERM+4EM).
The inoculation of EMs did not influence the final C/N ratio. Nevertheless, in the composting experiments, phosphorus levels were greater for both COMP+EM2 and COMP+EM4, and levels of N, K, and Ca were greater in COMP+EM4 compared to those in the COMP treatment.

Vermicomposting allowed an increased $\mathrm{C} / \mathrm{N}$ ratio, regardless of the concentration of EMs and C content, mainly in the VERM+EM4 experiment, compared to the VERM experiment. N, P, K, and Ca levels were slightly lower in the vermicomposting experiment and $4 \mathrm{~mL} \mathrm{~L}^{-1}$ EMs (Table 2).

The composting experiment (COMP) revealed greater availability of all micronutrients measured compared to baseline substrate contents (BASELINE) (Table 3). Similar responses were observed for $\mathrm{Mn}$, $\mathrm{Zn}, \mathrm{Fe}$, and $\mathrm{B}$ in the VERM experiment. The micronutrients $\mathrm{Mn}, \mathrm{Cu}$, $\mathrm{Zn}, \mathrm{Fe}$, and $\mathrm{B}$ had higher concentrations in the composting experiments compared to the vermicomposting processes.

Adding EMs, regardless of the concentration, did not significantly influence micronutrient content in either composting or vermicomposting processes. Slight reductions in $\mathrm{Mn}$ and Fe levels were observed in the COMP+EM2 and VERM+EM4 experiments compared to the COMP and VERM experiments, respectively.

As observed for nutrients in general, during the experimental period in both composting and vermicomposting processes, there was greater availability of heavy metals in the substrates (Table 4). Increased $\mathrm{Cd}, \mathrm{Pb}, \mathrm{Cr}$, and $\mathrm{Ni}$ levels were observed in the COMP experiment; and $\mathrm{Cd}, \mathrm{Cr}$, and Ni levels in the VERM experiment compared to baseline substrate levels. The presence of EMs resulted in lower $\mathrm{Cr}$ availability in composting and lower levels of $\mathrm{Ni}$ and $\mathrm{Cd}$ in vermicomposting. In general, the VERM experiments showed reduced content of the metals analyzed.

Thermotolerant coliforms were significantly lower in all processes used (Table 5). The higher concentration of EMs $\left(4 \mathrm{~mL} \mathrm{~L}^{-1}\right)$ resulted in lower detection of thermotolerant coliforms in the composting process, compared to the intermediate concentration (COMP+EM2).

Table 1 - $\mathrm{pH}$ values of each experiment: composting (COMP) or vermicomposting (VERM) with the addition of 0,2 , or $4 \mathrm{~mL} \mathrm{~L}^{-1}$ of efficient microorganisms (EMs) at the beginning (BASELINE) and after 120 or 150 experimental days.

\begin{tabular}{|l|c|c|}
\hline & Humidity $(\%)$ & $\mathrm{pH}$ \\
\hline BASELINE & 71.60 & 8.12 \\
\hline COMP & 50.17 & $7.21 \pm 0.02$ \\
\hline COMP+EM2 & 55.07 & $7.52 \pm 0.04$ \\
\hline COMP+EM4 & 49.56 & $7.59 \pm 0.01$ \\
\hline VERM & 61.90 & $6.72 \pm 0.02$ \\
\hline VERM+EM2 & 63.36 & $6.90 \pm 0.03$ \\
\hline VERM+EM4 & 66.95 & $6.73 \pm 0.03$ \\
\hline
\end{tabular}


Table 2 - Ratio of carbon to nitrogen $(\mathrm{C} / \mathrm{N})$ and organic carbon $(\mathrm{C}, \%)$, nitrogen $(\mathrm{N}, \%)$, phosphorus $(\mathrm{P}, \%)$, potassium $(\mathrm{K}, \%)$, calcium $(\mathrm{Ca}, \%)$, magnesium $(\mathrm{Mg}, \%)$ and sulfur $(\mathrm{S}, \%)$ in composting (COMP) or vermicomposting (VERM), with the addition of 0,2 (EM2) or 4 (EM4) $\mathrm{mL}^{-1}$ of efficient microorganisms (EMs) at the beginning (BASELINE) and after 120 or 150 experimental days*.

\begin{tabular}{|l|c|c|c|c|c|c|c|c|c|}
\hline & $\mathrm{C} / \mathrm{N}$ & $\mathbf{C}$ & $\mathbf{N}$ & $\mathbf{P}$ & $\mathrm{K}$ & $\mathrm{Ca}$ & $\mathrm{Mg}$ & $\mathbf{S}$ \\
\hline BASELINE & 19.26 & 35.50 & 0.52 & 0.50 & 0.32 & 0.39 & 0.11 \\
\hline COMP & $11.62 \pm 0.32$ & $20.30 \pm 0.45$ & $0.87 \pm 0.01$ & $0.83 \pm 0.01$ & $0.43 \pm 0.00$ & $0.83 \pm 0.01$ & $0.16 \pm 0.00$ & $0.47 \pm 0.06$ \\
\hline COMP + EM2 & $12.33 \pm 0.67$ & $23.26 \pm 0.76$ & $0.85 \pm 0.06$ & $0.90 \pm 0.05$ & $0.56 \pm 0.00$ & $0.86 \pm 0.00$ & $0.16 \pm 0.00$ & $0.38 \pm 0.05$ \\
\hline COMP + EM4 & $11.51 \pm 0.41$ & $22.78 \pm 0.41$ & $0.99 \pm 0.03$ & $0.96 \pm 0.01$ & $0.61 \pm 0.04$ & $0.99 \pm 0.01$ & $0.18 \pm 0.00$ & $0.45 \pm 0.04$ \\
\hline VERM & $12.12 \pm 0.20$ & $28.41 \pm 1.03$ & $0.90 \pm 0.01$ & $0.80 \pm 0.01$ & $0.28 \pm 0.02$ & $0.77 \pm 0.01$ & $0.26 \pm 0.02$ & $0.26 \pm 0.01$ \\
\hline VERM + EM2 & $12.78 \pm 1.23$ & $28.06 \pm 0.99$ & $0.82 \pm 0.03$ & $0.74 \pm 0.04$ & $0.30 \pm 0.01$ & $0.68 \pm 0.01$ & $0.25 \pm 0.00$ & $0.13 \pm 0.01$ \\
\hline VERM + EM4 & $13.12 \pm 0.07$ & $30.44 \pm 0.77$ & $0.77 \pm 0.02$ & $0.68 \pm 0.03$ & $0.23 \pm 0.00$ & $0.67 \pm 0.01$ & $0.23 \pm 0.01$ & $0.23 \pm 0.03$ \\
\hline
\end{tabular}

${ }^{*}$ Data represent means \pm standard deviation.

Table 3 - Content of micronutrients: manganese $\left(\mathrm{Mn}, \mathrm{mg} \mathrm{kg}^{-1}\right)$, copper $\left(\mathrm{Cu}, \mathrm{mg} \mathrm{kg}^{-1}\right)$, $\mathrm{zinc}\left(\mathrm{Zn}, \mathrm{mg} \mathrm{kg}^{-1}\right)$, iron $\left(\mathrm{Fe}, \mathrm{mg} \mathrm{kg}^{-1}\right)$, and boron $\left(\mathrm{B}, \mathrm{mg} \mathrm{kg}^{-1}\right)$ in composting (COMP) or vermicomposting (VERM), with the addition of 0,2 (EM2) or 4 (EM4) $\mathrm{mL} \mathrm{L}^{-1}$ of efficient microorganisms (EMs) at the beginning (BASELINE) and after 120 or 150 experimental days*.

\begin{tabular}{|l|c|c|c|c|c|}
\hline & Mn & Cu & Zn & Be \\
\hline BASELINE & 0.027 & 0.004 & 0.008 & 0.561 \\
\hline COMP & $0.079 \pm 0.003$ & $0.012 \pm 0.001$ & $0.016 \pm 0.000$ & $3.754 \pm 0.161$ \\
\hline COMP+EM2 & $0.065 \pm 0.000$ & $0.009 \pm 0.001$ & $0.014 \pm 0.000$ & $2.678 \pm 0.048$ \\
\hline COMP+EM4 & $0.073 \pm 0.000$ & $0.011 \pm 0.002$ & $0.016 \pm 0.001$ & $2.858 \pm 0.042$ & $0.006 \pm 0.000$ \\
\hline VERM & $0.055 \pm 0.001$ & $0.007 \pm 0.000$ & $0.013 \pm 0.000$ & $1.959 \pm 0.053$ \\
\hline VERM+EM2 & $0.054 \pm 0.001$ & $0.006 \pm 0.000$ & $0.011 \pm 0.000$ & $1.982 \pm 0.012$ & $0.009 \pm 0.000$ \\
\hline VERM+EM4 & $0.047 \pm 0.000$ & $0.006 \pm 0.000$ & $0.011 \pm 0.000$ & $1.572 \pm 0.014$ \\
\hline
\end{tabular}

${ }^{\star}$ Data represent means \pm standard deviation.

Table 4 - Cadmium (Cd, $\left.\mathrm{mg} \mathrm{kg}^{-1}\right)$, lead ( $\left.\mathrm{Pb}, \mathrm{mg} \mathrm{kg}^{-1}\right)$, chromium (Cr, mg $\left.\mathrm{kg}^{-1}\right)$, and nickel $\left(\mathrm{Ni}, \mathrm{mg} \mathrm{kg}^{-1}\right)$ in composting (COMP) or vermicomposting (VERM), with the addition of 0,2 (EM2) or 4 (EM4) $\mathrm{mL} \mathrm{L}^{-1}$ of efficient microorganisms (EMs) at the beginning (BASELINE) and after 120 or 150 experimental days*.

\begin{tabular}{|l|c|c|c|c|}
\hline & $\mathrm{Cd}$ & $\mathrm{Pb}$ & $\mathrm{Cr}$ & $\mathrm{Ni}$ \\
\hline BASELINE & 1.76 & 20.7 & 2.8 & 13.8 \\
\hline COMP & $2.77 \pm 0.19$ & $53.30 \pm 0.00$ & $15.47 \pm 1.02$ & $27.56 \pm 1.11$ \\
\hline COMP+EM2 & $2.33 \pm 0.00$ & $53.30 \pm 0.00$ & $10.70 \pm 0.00$ & $21.50 \pm 0.00$ \\
\hline COMP+EM4 & $2.22 \pm 0.19$ & $57.76 \pm 3.86$ & $9.52 \pm 1.02$ & $21.79 \pm 1.11$ \\
\hline VERM & $2.03 \pm 0.08$ & $21.70 \pm 3.10$ & $7.36 \pm 0.98$ & $18.54 \pm 0.61$ \\
\hline VERM+EM2 & $2.18 \pm 0.09$ & $21.70 \pm 0.01$ & $6.23 \pm 0.98$ & $18.90 \pm 0.61$ \\
\hline VERM+EM4 & $2.41 \pm 0.00$ & $21.70 \pm 0.00$ & $6.23 \pm 0.98$ & $17.83 \pm 1.63$ \\
\hline
\end{tabular}

${ }^{*}$ Data represent means \pm standard deviation.
Table 5 - Content of thermotolerant coliforms (NMP $\mathrm{g}^{-1}$ ) and Salmonella spp. (in $10 \mathrm{~g}$ ) in composting (COMP) or vermicomposting (VERM), with the addition of 0,2 (EM2), or 4 (EM4) $\mathrm{mL} \mathrm{L}^{-1}$ of efficient microorganisms (EMs) at the beginning (BASELINE) and after 120 or 150 experimental days.

\begin{tabular}{|l|c|c|}
\hline & Thermotolerant coliforms & Salmonella ssp. \\
\hline BASELINE & $>160,000$ & Absent \\
\hline COMP & 14,000 & Absent \\
\hline COMP+EM2 & 17,000 & Absent \\
\hline COMP+EM4 & 400 & Absent \\
\hline VERM & 4,900 & Absent \\
\hline VERM+EM2 & 200 & Absent \\
\hline VERM+EM4 & 1,100 & Absent \\
\hline
\end{tabular}


For vermicomposting experiments, the intermediate concentration of EMs (VERM+EM2) was more efficient in reducing coliforms. Salmonella ssp. were observed either in the initial substrate used in the processes or at the end of the experimental period.

\section{Discussion}

We analyzed the physicochemical characteristics and the presence of pathogens in composting and vermicomposting from cattle manure, goat manure, and sawdust associated with efficient microorganisms, under field conditions. It is important to keep the compost moist (50-75\%) to allow a high-quality final product, considering that this condition ensures microbiological activity (Makan et al., 2013; Kabelitz et al., 2020; 2021), as observed in the present study. Substrate moisture, although slightly reduced in the COM and VERM experiments, probably due to greater soil aeration after turning and the action of earthworms, respectively, remained at adequate levels for the activity of microorganisms. Compost temperature is an indication of the phase of the process. The composting process begins in the adaptation or mesophilic phase, with the adaptation of microorganisms. Subsequently, at temperatures above $50^{\circ} \mathrm{C}$, the process reaches the thermophilic phase, which is fundamental to ensure pathogen elimination and to assist in the elimination of invasive plant seeds from the compost (Huhe et al., 2017; Ribeiro et al., 2017). The stability of the compost is observed during the maturation or humification phase, when temperatures tend to decrease to room temperature levels. For effective elimination of pathogens and weeds, the thermophilic phase must reach temperatures above $50^{\circ} \mathrm{C}$ for at least 15 consecutive days, (Brenes-Peralta et al., 2021). In this sense, the maximum temperature range found and process acceleration occurred due to the presence of EMs that intensified the thermophilic phase responsible for this thermal behavior. EMs also help balance nutrient supplies by slowly releasing organically bound nutrients. They contribute to beneficial microbes that, together with native microorganisms, promote greater microbial activity (Ribeiro et al., 2017; Sharma et al., 2017; Rastogi et al., 2020) and higher temperatures, with improved efficiency and compost quality (Tran et al., 2019). The maturation phase is also affected by substrate composition. Mechanical rotation, as performed in the composting experiments, promotes greater aeration and homogenization of the compost. In the vermicomposting process, this rotation is performed exclusively by the earthworms present, which makes the process slower, thereby creating longer intervals to reach stability. In the present study, the vermicomposting processes were stabilized about 30 days after the composting processes (it took $25 \%$ longer).

Because temperature affects microbiota activity, compost $\mathrm{pH}$ is also regulated by the microorganisms present. They are responsible for degrading the organic matter while producing acidic or basic byproducts and $\mathrm{CO}_{2}$ (Morales et al., 2016; Osman et al., 2020). At the end of the process, we found that more alkaline $\mathrm{pH}$ values were record- ed in the composting experiments compared to the vermicomposting experiments. This may have occurred because the substrate was not turned in the vermicomposting experiments. Although the presence of earthworms allows for compost oxygenation, turning the substrate in the composting treatments possibly caused greater oxygenation and, consequently, a higher $\mathrm{pH}$ value. The addition of EMs also favored high $\mathrm{pH}$, regardless of the inoculated concentration. $\mathrm{pH}$ values between 6 and 8 are considered suitable conditions for composting (Bustamante et al., 2013; Jerônimo et al., 2020), as observed in the present study. This represents an important advantage and suggests that the mineralization and humification reactions occurring in the present study occurred under favorable biochemical conditions, resulting in high-quality organic compost.

Biodegradation of organic matter can be assessed using the $\mathrm{C} / \mathrm{N}$ ratio, which indicates the stabilization of organic fertilizers ( $\mathrm{Nafez}$ et al., 2020; Nayak et al., 2020; Palaniveloo et al., 2020). Bioconversion of cattle and goat manure, with composting or vermicomposting, resulted in lower $\mathrm{C} / \mathrm{N}$ ratios compared to baseline levels. This may occur due to the degradation of putrid organic matter, promoting nutrient mineralization. Subsequently, in the final humification and maturation phase, organic matter is formed in a stable state, in the form of complexes (predominantly humic acid, humine, and fulvic acid), which hold these nutrients in a weak link, available for and exchangeable by the plants. It results in increased bioavailability and mobility of key plant nutrients, such as $\mathrm{K}, \mathrm{P}$, and $\mathrm{N}$, as facilitators of plant development, especially those that are not nitrogen fixers. On the other hand, EMs had no effect on the biodegradation of the substrate, possibly because they play a major role in increasing microbiological activity, allowing for a better nutrient stock and increasing the effect of the earthworms, among other things; and not in increasing the temperature and intensifying the thermophilic phase. In addition, the $\mathrm{C} / \mathrm{N}$ ratio observed in the experiments is suitable for composting $(<20)$ and vermicomposting (<14), according to MAPA Normative Instruction (Brasil, 2009). $\mathrm{A} \mathrm{C} / \mathrm{N}$ ratio between 12 and 15 at the end of the composting process indicates compost maturity and ideal conditions for fertilization (Onwosi et al., 2017; Nafez et al., 2020).

Cattle and goat manure composting and vermicomposting showed higher contents for all macronutrients evaluated at the end of the process compared to the baseline quantification of the substrate. The composting processes yielded higher contents of $\mathrm{P}, \mathrm{K}, \mathrm{Ca}$, and $\mathrm{S}$ compared to the vermicomposting processes. In the vermicomposting process, intense degradation of organic compounds due to synergistic action between microorganisms and earthworms was expected, resulting in greater mineralization of organic $P$, for example (Eckhardt et al., 2018).

Increased macronutrients in composting and vermicomposting were expected because minerals are solubilized during biodegradation and nitrogen compounds are released. However, it was more evident in COMP+EM4 compared to COMP, where the content of $\mathrm{P}, \mathrm{K}, \mathrm{Ca}$, 
and $\mathrm{Mg}$ was higher. A larger number of EMs has also been described as improving the levels of $\mathrm{N}, \mathrm{P}$, and $\mathrm{K}$ in the compost, regardless of the EM multiplication medium (Sharma et al., 2017; Nayak et al., 2020). Greater aeration in the COMP experiments may have allowed Ems to perform better, further increasing degradation. Hendriani et al. (2017) reported that EMs associated with Azotobater sp. in the composting of corn by-products promoted an increase in the content of macronutrients, such as N, P, and K (Hendriani et al., 2017). According to the authors, the use of the final compost as fertilizer also allowed greater productivity to pepper and tomato plants. However, the nutrient content of organic fertilizers also depends on the composition of the source material (Tratsch et al., 2019; Jerônimo et al., 2020; Wako et al., 2021). In vermicomposting experiments, macronutrient content was significantly higher when compared to BASELINE values. Vermicomposting processes can even promote residual effects for subsequent planting, as observed by Nurhidayati et al. (2018). This demonstrates the importance of adapting these processes on small farms to increase the value of residues and to reduce potential environmental contamination, all of which will reduce the need for chemical fertilizers.

Micronutrient content, such as $\mathrm{Mn}, \mathrm{Cu}, \mathrm{Zn}, \mathrm{Fe}$, and $\mathrm{B}$, increased after composting and vermicomposting when compared to BASELINE values, regardless of EM inoculation, but were even lower in vermicomposting experiments when compared to composting. The low levels of micronutrients and heavy metals in VERM may be related to the high C levels observed in these treatments; which allowed adsorption of these elements by complexing metal ions, lowering their available concentration.

The levels of micronutrients available at the end of the process, although at a lower concentration than the ones required for crops (as compared to traditional chemical fertilizers available for sale), are important waste recovery products. This represents an economic and sustainable advantage, reducing the need for chemical fertilizers in gardening, ornamentation, and vegetable growing, especially on small farms.

The heavy metals found in the substrate tend to increase when compared to the BASELINE values because they are not degradable (Soobhany et al., 2015). However, in addition to the negative correlation with organic matter, the use of earthworm bioconversion in vermicomposting processes allowed for lower contents of $\mathrm{Pb}, \mathrm{Cr}$, and $\mathrm{Ni}$ compared to composting processes. This was possibly because earthworms absorbed these metals. The level of accumulation carried out by the worms will depend on the species of the earthworm and the amount of metal present; but several studies have reported that earthworms are potential bioaccumulators of metals in contaminated soils (Lv et al., 2016; Zeb et al., 2020; Xiao et al., 2021).

It should be noted that the main effect of organic fertilizers is not to enrich the soil, but rather make nutrients available slowly and continuously, which is typical of organic fertilizers produced by composting. Among other factors, they can contribute to improving soil structure by increasing porosity and gas exchange, stabilizing organic matter, and increasing microbial diversity (Rauber et al., 2018), all of which contribute to nutrient mobilization for plants. Furthermore, inoculation of microorganisms such as EMs contributes to the degradation of toxic agents (Boechat et al., 2020; Dell'Anno et al., 2020), and the control of plant pathogens (Shen et al., 2013; Alori et al., 2017; Benedetti et al., 2021). The use of these compost products for agroecological production is also environmentally friendly because excess chemical fertilizers, in addition to degrading the soil, can leach into water resources causing environmental impacts such as eutrophication (Chislock et al., 2013; Rivas et al., 2020).

Salmonella was not detected in the analyses because of the initial preparation of the compost, suggesting that the cattle and goat manure were free from contamination; Salmonella is often observed in chicken manure (Sheffield et al., 2014). Thermotolerant coliforms, as expected for the type of waste used, were found at high concentrations in the initial preparation of the compost. These high concentrations were drastically reduced in all experiments, with the lowest levels observed in the composting treatment and the treatment with the highest concentration of EMs ( $\left.4 \mathrm{~mL} \mathrm{~L}^{-1}\right)$, and in vermicomposting inoculated with EMs ( $2 \mathrm{~mL}$ $\mathrm{L}^{-1}$ ). These values were below the limit of $1,000 \mathrm{MPN} \mathrm{g}^{-1}$ of dry matter determined by the legislation (Brasil, 2016). Hénault-Ethier et al. (2016) studied the survival of Escherichia coli in different reactor scales, with and without the presence of earthworms and efficient microorganisms, and observed that a rich microbial community was the most important factor in determining the survival of $E$. coli. Lower concentrations of thermotolerant coliforms were observed in the experiments with higher concentrations of EMs. However, the role of EMs in the elimination of thermotolerant coliforms depends on the maximum temperature range in the thermophilic phase (Hénault-Ethier et al., 2016). The maximum temperature range was not significant in the present study and suggests that the effect may also be related to the increased richness of the microbial community, which stimulated the development of microorganisms antagonistic to the presence of thermotolerant coliforms.

Lower concentrations of thermotolerant coliforms were also observed in the vermicomposting experiments. Therefore, this can be considered an additional effect that also influenced reduction. During the vermicomposting process, some earthworm species may ingest and kill pathogenic microorganisms such as E. coli, Salmonella spp., and total coliforms (Soobhany et al., 2017). According to these authors, vermicomposting is an efficient technique to remove pathogenic microorganisms, especially in the mesophilic phase, as Salmonella suppression was more efficient at $55^{\circ} \mathrm{C}$ than at $70^{\circ} \mathrm{C}$.

\section{Conclusion}

The composting experiments using cattle and goat manure, regardless of the presence of efficient microorganisms, allowed for higher humidity and lower $\mathrm{pH}$ of the final compost, probably due to substrate turning.

The percentage of organic carbon and $\mathrm{Mg}$ was higher in the vermicomposting treatments; while the other macronutrients $(\mathrm{P}, \mathrm{K}, \mathrm{Ca}$, and 
S) were found at greater levels in the composting treatments. The presence of EMs, mainly EM4, in the composting treatments, favored increased content of most of the macronutrients in the final compost.

Micronutrients and heavy metals were observed at a higher percentage in composting treatments, regardless of the presence of EMs. On the other hand, vermicomposting was more effective in removing pathogens such as thermotolerant coliforms, mainly when associated with EM2. Composting and vermicomposting processes have been shown to allow waste to have increased value and generate quality products that can be used in agroecological production in small rural properties.

\section{Contribution of authors:}

Panisson, R.: Conceptualization, Methodology, Conducting Experiments, Data Analysis, Writing - Original Draft; Muscope, F.P.: Methodology, Conducting Experiments, Data Analysis; Muller, C.: Conceptualization, Methodology, Data Analysis, Writing — Original Draft; Writing — Review \& Edition; Treichel, H.: Conceptualization, Methodology, Resources, Supervision; Korf, E.P.: Conceptualization, Resources, Data Analysis, Writing — Original Draft, Project Administration.

\section{References}

Albiach, R.; Canet, R.; Pomares, F.; Ingelmo, F., 2000. Microbial biomass content and enzymatic activities after the application of organic amendments to a horticultural soil, Bioresource Technology, v. 75, (1), 43-48. https://doi. org/10.1016/S0960-8524(00)00030-4.

Alori, E.T.; Dare, M.O.; Babalola, O.O., 2017. Microbial inoculants for soil quality and plant health. In: Lichtfouse, E. (Ed.), Sustainable agriculture reviews. Springer, Cham, v. 22, pp. 281-307.

Benedetti, T.; Huzar-Novakowiski, J.; Sordi, E.; Carvalho, I.R.; Bortoluzzi, E.C., 2021. Microorganisms in the biological control of root-knot nematode: a metanalytical study. Research, Society and Development, v. 10, (6), e39310615209. https://doi.org/10.33448/rsd-v10i6.15209.

Boechat, C.L.; Carlos, F.S.; Nascimento, C.W.A.; Quadros, P.D.; Sá, E.L.S.; Camargo, F.A.O., 2020. Bioaugmentation-assisted phytoremediation of As, Cd, and $\mathrm{Pb}$ using Sorghum bicolor in a contaminated soil of an abandoned gold ore processing plant. Revista Brasileira de Ciência do Solo, v. 44, e0200081. https://doi.org/10.36783/18069657rbcs20200081.

Bonfin, F.P.G.; Honorio, I.C.G.; Reis, I.L.; Pereira, A.J.; Souza, D.B., 2011. Caderno dos microrganismos eficientes (EM): Instruções práticas sobre uso ecológico e social do EM. Universidade Federal de Viçosa, Viçosa.

Brasil. Ministério da Agricultura, Pecuária e Abastecimento - MAPA. 2009. Instrução Normativa SDA no 25, de 23 de julho de 2009. Ministério da Agricultura, Pecuária e Abastecimento. Brasília (Accessed October 4, 2020) at: http://www.agricultura.gov.br/assuntos/insumos-agropecuarios/ insumos-agricolas/fertilizantes/legislacao/in-25-de-23-7-2009-fertilizantesorganicos.pdf

Brasil. Ministério da Agricultura, Pecuária e Abastecimento - MAPA. 2016. Instrução Normativa SDA no 7, de 12 de abril de 2016. Ministério da Agricultura, Pecuária e Abastecimento, Brasília (Accessed October 4, 2020) at: http://www.limpezapublica.com.br/textos/limites_maximos_de_ contaminantes_admitidos_em_substrato_.pdf.

Brasil. Ministério da Agricultura, Pecuária e Abastecimento - MAPA. 2017. Manual de métodos analíticos oficiais para fertilizantes e corretivos. Ministério da Agricultura, Pecuária e Abastecimento, Brasília.

Braun-Howland, E.B.; Best, J.; Blodgett, R.J.; Boczek, L.; Dichter, G.; Johnson, C.H., 2017. 9221 Multiple-tube fermentation technique for members of the coliform group. In: Baird, R.B.; Andrew, D.E.; Rice, E.W. (Eds.), Standard Methods for the examination of water and wastewater, (Method: 9221E). American Public Health Association, Washington, D.C., pp. 1-12.
Brenes-Peralta, L.P.; Jiménez-Morales, M.F.; Campos-Rodríguez, R., 2021. Food waste valorization through composting and bio-drying for small scale fruit processing agro-industries. Ingeniería y Competitividad, v. 23, (1), e9623. https://doi.org/10.25100/iyc.v23i1.9623.

Bustamante, M.A.; Restrepo, A.P.; Alburquerque, J.A.; Pérez-Murcia, M.D.; Paredes, C.; Moral, R.; Bernal, M.P., 2013. Recycling of anaerobic digestates by composting: effect of the bulking agent used. Journal of Cleaner Production, v. 47, 61-69. https://doi.org/10.1016/j.jclepro.2012.07.018.

Calderón-Tapia, C.; Montero-Calderón, A.; Núñez-Moreno, M.; PazmiñoArias, E., 2020. Laboratory scale evaluation of Effective Microorganisms in the control of odor of organic waste from a market in the city of Riobamba, Ecuador. Bionatura, v. 5, (1), 1044-1049. https://doi.org/10.21931/RB/2020.05.01.6.

Chislock, M.F.; Doster, E.; Zitomer, R.A.; Wilson, A.E., 2013. Eutrophication: causes, consequences, and controls in aquatic ecosystems. Nature Education Knowledge, v. 4, (4), 10

Ciancio, N.R.; Ceretta, C.A.; Lourenzi, C.R.; Ferreira, P.A.A.; Trentin, G.; Lorensini, F.; Tiecher, T.L.; Conti, L.; Girotto, E.; Brunetto, G., 2014. Crop response to organic fertilization with supplementary mineral nitrogen. Revista Brasileira de Ciência do Solo, v. 38, (3), 912-922. https://doi.org/10.1590/S0100-06832014000300023.

Ciapparelli, I.C.; Iorio, A.F.; García, A.R., 2016. Phosphorus downward movement in soil highly charged with cattle manure. Environmental Earth Science, v. 75, 568. https://doi.org/10.1007/s12665-016-5284-3.

Dell'anno, F.; Brunet, C.; Van Zyl, L.J.; Trindade, M.; Golyshin, P.N.; Dell'anno, A.; Ianora, A.; Sansone, C., 2020. Degradation of hydrocarbons and heavy metal reduction by marine bacteria in highly contaminated sediments. Microorganisms, v. 8, (9), 1402. https://dx.doi. org/10.3390\%2Fmicroorganisms 8091402 .

Diering, N.L., 2020. Efeitos de microrganismos eficientes no porta-enxerto Poncirus trifoliata (L.) Raf e nos cultivos da laranja Valência e do Tangor Murccot. Universidade Federal da Fronteira Sul, Erechim.

Domínguez, J.; Gómez-Brandón, M., 2013. The influence of earthworms on nutrient dynamics during the process of vermicomposting. Waste Management \& Research, v. 31, (8), 859-868. https://doi.org/10.1177/0734242x13497079.

Eckhardt, D.P.; Redin, M.; Santana, N.A.; Conti, L.; Dominguez, J.; Jacques, R.J.S.; Antoniolli, Z.I., 2018. Cattle manure bioconversion effect on the availability of nitrogen, phosphorus, and potassium in soil. Revista Brasileira de Ciência do Solo, v. 42, e0170327. https://doi.org/10.1590/18069657rbcs20170327. 
Elbl, J.; Maková, J.; Javoreková, S.; Medo, J.; Kintl, A.; Lošák, T.; Lukas, V., 2019. Response of microbial activities in soil to various organic and mineral amendments as an indicator of soil quality. Agronomy, v. 9, (9), 485. https:// doi.org/10.3390/agronomy9090485.

Ermolaev, E.; Sundberg, C.; Pell, M.; Jönsson, H., 2014. Greenhouse gas emissions from home composting in practice. Bioresource Technology, v. 151, 174-182. https://doi.org/10.1016/j.biortech.2013.10.049.

Faverial, J.; Sierra, J., 2014. Home composting of household biodegradable wastes under the tropical conditions of Guadeloupe (French Antilles). Journal of Cleaner Production, v. 83, 238-244. https://doi.org/10.1016/j. jclepro.2014.07.068.

Hemidat, S.; Jaar, M.; Nassour, A.; Nelles, M., 2018. Monitoring of composting process parameters: a case study in Jordan. Waste and Biomass Valorization, v. 9, 2257-2274. https://doi.org/10.1007/s12649-018-0197-x.

Hénault-Ethier, L.; Martin, V.J.; Gélinas, Y., 2016. Persistence of Escherichia coli in batch and continuous vermicomposting systems. Waste Management, v. 56, 88-99. https://doi.org/10.1016/j.wasman.2016.07.033.

Hendriani, N.; Juliastuti, S.R.; Masetya, H.N.; Saputra, I.T.A., 2017. Composting of corn by-product using EM4 and microorganism Azotobacter sp. as composting organism. KnE Life Sciences, v. 3, (5), 158-166. http://dx.doi. org/10.18502/kls.v3i5.988.

Herberts, R.A.; Coelho, C.R. de A.; Miletti, L.C.; Mendonça, M.M., 2005. Composting of organic solid waste: biotechnology. Health and Environmental Journal, v. 6, (1), 41-50.

Huhe; Jiang, C.; Wu, Y.; Cheng, Y., 2017. Bacterial and fungal communities and contribution of physicochemical factors during cattle farm waste composting. Microbiologyopen, v. 6, (6), e00518. https://dx.doi.org/10.1002\%2Fmbo3.518.

Jerônimo, G.; Senhuk, A.; Luz, M.; Gonçalves, J.; Ferreira, D., 2020. Efficiency of biocompost potentiated with chemical fertilizer and facilitated aeration. Ciência e Natura, v. 42, e31. https://doi.org/10.5902/2179460X41908.

Jusoh, M.L.C.; Manaf, L.A.; Latiff, P.A., 2013. Composting of rice straw with effective microorganisms (EM) and its influence on compost quality. Iranian Journal of Environmental Health Science \& Engineering, v. 10, (1), 17. https:// doi.org/10.1186/1735-2746-10-17.

Kabelitz, T.; Ammon, C.; Funk, R.; Münch, S.; Biniasch, O.; Nübel, U.; Thiel, N.; Rösler, U.; Siller, P.; Amon, B.; Aarnink, A.J.A.; Amon, T., 2020. Functional relationship of particulate matter (PM) emissions, animal species, and moisture content during manure application. Environment International, v. 143, 105577. https://doi.org/10.1016/j.envint.2020.105577.

Kabelitz, T.; Biniasch, O.; Ammon, C.; Nübel, U.; Thiel, N.; Janke, D.; Swaminathan, S.; Funk, R.; Münch, S.; Rösler, U.; Siller, P.; Amon, B.; Aarnink, A.J.A.; Amon, T., 2021. Particulate matter emissions during field application of poultry manure - The influence of moisture content and treatment. Science of The Total Environment, v. 780, 146652. https://doi.org/10.1016/j. scitotenv.2021.146652.

Knapp, B.A.; Ros, M.; Insam, H., 2010. Do composts affect the soil microbial community? In: Insam, H.; Franke-Whittle, I.; Goberna, M. (Eds), Microbes at work: from wastes to resources. Springer, Berlin, Heidelberg, pp. 271-291.

Komiyama, T.; Kobayashi, A.; Yahag, M., 2013. The chemical characteristics of ashes from cattle, swine and poultry manure. Journal of Material Cycles and Waste Management, v. 15, (1), 106-110. https://doi.org/10.1007/s10163-012-0089-2.

Larney, F.J.; Hao, X., 2007. A review of composting as a management alternative for beef cattle feedlot manure in southern Alberta, Canada. Bioresource Technology, v. 98, (17), 3221-3227. https://doi.org/10.1016/j. biortech.2006.07.005.
Lim, S.L.; Lee, L.H.; Wu, T.Y., 2016. Sustainability of using composting and vermicomposting technologies for organic solid waste biotransformation: recent overview, greenhouse gases emissions and economic analysis. Journal of Cleaner Production, v. 111, (Part A), 262-278. https://doi.org/10.1016/j. jclepro.2015.08.083.

Lv, B.; Xing, M.; Yang, J., 2016. Speciation and transformation of heavy metals during vermicomposting of animal manure. Bioresource Technology, v. 209, 397-401. https://doi.org/10.1016/j.biortech.2016.03.015.

Makan, A.; Assobhei, O.; Mountadar, M., 2013. Effect of initial moisture content on the in-vessel composting under air pressure of organic fraction of municipal solid waste in Morocco. Journal of Environmental Health Science and Engineering, v. 10, (1), 3. https://dx.doi.org/10.1186\%2F1735-2746-10-3.

Misra, R.V.; Ray, R.N.; Hiraoka, H., 2003. On-farm composting methods. Food and Agriculture Organization of the United Nations, Rome.

Morales, D.; Vargas, M.M.; Oliveira, M.P.; Taffe, B.L.; Comin, J.; Soares, C.R.; Lovato, P., 2016. Response of soil microbiota to nine-year application of swine manure and urea. Ciência Rural, v. 46, (2), 260-266. https://doi. org/10.1590/0103-8478cr20140565.

Nafez, A.H.; Nikaeen, M.; Hassanzadeh, A.; Kadkhodaei, S., 2020. Changes in microbial populations during co-composting of dewatered sewage sludge with pruning wastes in windrow piles. Biodiversitas, v. 21, (10), 4655-4662.

Nath, G.; Singh, K., 2012. Effect of vermiwash of different vermicomposts on the kharif crops. Journal of Central European Agriculture, v. 13, (2), 379-402. https://doi.org/10.5513/JCEA01/13.2.1063.

Nayak, N.; Sar, K.; Sahoo, B.K.; Mahapatra, P., 2020. Beneficial effect of effective microorganism on crop and soil - a review. Journal of Pharmacognosy and Phytochemistry, v. 9, (4), 3070-3074.

Nunes, M.U.C., 2009. Compostagem de resíduos para produção de adubo orgânico na pequena propriedade. Circular técnica 59, Embrapa, Aracaju, 1-7.

Nurhidayati, N.; Machfudz, M.; Murwani, I., 2018. Direct and residual effect of various vermicompost on soil nutrient and nutrient uptake dynamics and productivity of four mustard Pak-Coi (Brassica rapa L.) sequences in organic farming system. International Journal of Recycling of Organic Waste in Agriculture, v. 7, (2), 173-181. https://doi.org/10.1007/s40093-018-0203-0.

Onwosi, C.O.; Igbokwe, V.C.; Odimba, J.N.; Ifeanyichukwu, E.E.; Nwankwoala, M.O.; Iroh, I.N.; Ezeogu, L.J., 2017. Composting technology in waste stabilization: On the methods, challenges and future prospects. Journal of Environmental Management, v. 190, 140-157. HTTPS://DOI.ORG/10.1016/J. JENVMAN.2016.12.051.

Osman, A.I.; Deka, T.J.; Baruah, D.C.; Rooney, D.W., 2020. Critical challenges in biohydrogen production processes from the organic feedstocks. Biomass Conversion and Biorefinery. https://doi.org/10.1007/s13399-020-00965-x.

Palaniveloo, K.; Amran, M.A.; Norhashim, N.A.; Mohamad-Fauzi, N.; Peng-Hui, F.; Hui-Wen, L.; Kai-Lin, Y.; Jiale, L.; Chian-Yee, M.G.; JingYi, L.; Gunasekaran, B.; Razak, S.A., 2020. Food waste composting and microbial community structure profiling. Processes, v. 8, (6), 723. https://doi. org/10.3390/pr8060723.

Patidar, A.; Gupta, R.; Tiwari, A., 2013. Potential of microbial inoculated water hyacinth amended thermophilic composting and vermicomposting in biodegradation of agro-industrial waste. Journal of Bioremediation \& Biodegradation, v. 4, (5), 191. https://doi.org/10.4172/2155-6199.1000191.

Raja Namasivayam, S.K.; Bharani, R.S.A., 2012. Effect of compost derived from decomposed fruit wastes by effective microorganism (EM) technology on plant growth parameters of Vigna mungo. Journal of Bioremediation \& Biodegradation, v. 3, (11), 167. https://doi.org/10.4172/2155-6199.1000167. 
Rastogi, M.; Nandal, M.; Khosla, B., 2020. Microbes as vital additives for solid waste composting. Heliyon, v. 6, (2), e03343. https://doi.org/10.1016/j. heliyon.2020.e03343.

Rauber, L.P.; Andrade, A.P.; Friederichs, A.; Mafra, A.L.; Baretta, D.; Rosa, M.G.; Mafra, M.S.H.; Correa, J.C., 2018. Soil physical indicators of management systems in traditional agricultural areas under manure application. Scientia Agricola, v. 75, (4), 354-359. https://doi. org/10.1590/1678-992X-2016-0453.

Ribeiro, N.Q.; Souza, T.P.; Costa, L.M.A.S.; Castro, C.P.; Dias, E.S., 2017. Microbial additives in the composting process. Ciência e Agrotecnologia, v. 41, (2), 159-168. https://doi.org/10.1590/1413-70542017412038216.

Rivas, E.J.G.; Pérez, G.R.; Tundisi, J.G.; Vammen, K.; Örmeci, B.; Forde, M., 2020. Eutrophication: a growing problem in the Americas and the Caribbean. Brazilian Journal of Biology, v. 80, (3), 688-689. https://doi.org/10.1590/1519-6984.200001.

Ros, M.; Pascual, J.A.; García, C.; Hernández, M.T.; Insam, H., 2006. Hydrolase activities, microbial biomass and bacterial community in a soil after long-term amendment with different composts. Soil Biology and Biochemistry, v. 38, (12), 3443-3452. http://dx.doi.org/10.1016/j.soilbio.2006.05.017.

Sharma, A.; Saha, T.N.; Arora, A.; Shah, R.; Nain, L., 2017. Efficient microorganism compost benefits plant growth and improves soil health in calendula and marigold. Horticultural Plant Journal, v. 3, (2), 67-72. https:// doi.org/10.1016/j.hpj.2017.07.003

Sheffield, C.L.; Crippen, T.L.; Beier, R.C.; Byrd, J.A. 2014. Salmonella Typhimurium in chicken manure reduced or eliminated by addition of LT1000. Journal of Applied Poultry Research, v. 23, (1), 116-120. https://doi.org/10.3382/japr.2013-00867.

Shen, Z.; Zhong, S.; Wang, Y.; Wang, B.; Mei, X.; Li, R.; Ruan, Y.; Shen, Q., 2013. Induced soil microbial suppression of banana fusarium wilt disease using compost and biofertilizers to improve yield and quality. European Journal of Soil Biology, v. 57, 1-8. https://doi.org/10.1016/j.ejsobi.2013.03.006.

Sigstad, E.E.; Schabes, F.I.; Tejerina, F.A., 2013. A calorimetric analysis of soil treated with effective microorganisms. Thermochimica Acta, v. 569, 139-143. https://doi.org/10.1016/j.tca.2013.07.007.

Soobhany, N.; Mohee, R.; Garg, V.K., 2015. Comparative assessment of heavy metals content during the composting and vermicomposting of municipal solid waste employing Eudrilus eugeniae. Waste Management, v. 39, 130-145. https://doi.org/10.1016/j.wasman.2015.02.003.
Soobhany, N.; Mohee, R.; Garg, V.K., 2017. Inactivation of bacterial pathogenic load in compost against vermicompost of organic solid waste aiming to achieve sanitation goals: A review. Waste Management, v. 64, 51-62. https://doi.org/10.1016/j.wasman.2017.03.003.

Tran, Q.N.M.; Mimoto, H.; Koyama, M.; Nakasaki, K., 2019. Lactic acid bacteria modulate organic acid production during early stages of food waste composting. Science of the Total Environment, v. 687, 341-347. https://doi. org/10.1016/j.scitotenv.2019.06.113.

Tratsch, M.V.M.; Ceretta, C.A.; Silva, L.S.; Ferreira, P.A.A.; Brunetto, G., 2019. Composition and mineralization of organic compost derived from composting of fruit and vegetable waste. Revista Ceres, v. 66, (4), 307-315. https://doi.org/10.1590/0034-737X201966040009.

United States Environmental Protection Agency - USEPA. 1998. Method 3050B. USEPA (Accessed February 4. 2017) at: https://www.epa.gov/sites/ default/files/2015-06/documents/epa-3050b.pdf.

Wako, R.E., 2021. Preparation and characterization of vermicompost made from different sources of materials. Open Journal of Plant Science, v. 6, (1), 42-48. https://doi.org/10.17352/ojps.000031.

Xiao, R.; Liu, X.; Ali, A.; Chen, A.; Zhang, M.; Li, R.; Chang, H.; Zhang, Z., 2021. Bioremediation of Cd-spiked soil using earthworms (Eisenia fetida): Enhancement with biochar and Bacillus megatherium application. Chemosphere, v. 264, (part 2), 128517. https://doi.org/10.1016/j. chemosphere.2020.128517.

Yadav, A.; Garg, V.K., 2016. Influence of stocking density on the vermicomposting of an effluent treatment plant sludge amended with cow dung. Environmental Science and Pollution Research, v. 23, (13), 1331713326. https://doi.org/10.1007/s11356-016-6522-7.

Zeb, A.; Li, S.; Wu, J.; Lian, J.; Liu, W.; Sun, Y., 2020. Insights into the mechanisms underlying the remediation potential of earthworms in contaminated soil: A critical review of research progress and prospects. Science of The Total Environment, v. 740, 140145. https://doi.org/10.1016/j. scitotenv.2020.140145.

Zhong, Z.; Bian, F.; Zhang, X., 2018. Testing composted bamboo residues with and without added effective microorganisms as a renewable alternative to peat in horticultural production. Industrial Crops and Products, v. 112, 602-607. https://doi.org/10.1016/j.indcrop.2017.12.043. 